\title{
Appendicular origin and structure of the spur of Vochysiaceae flowers
}

\author{
Renata Carmo-Oliveira* ${ }^{1 \star}$ Paulo E. Oliveira' and Berta Lange de Morretes $^{2}$
}

Received: March 25, 2017

Accepted: May 17, 2017

\begin{abstract}
Floral nectaries are linked with animal pollinators and floral specialization, characterizing some plant groups, such as the mostly Neotropical Vochysiaceae. The phylogeny of these plants has been revised based on molecular data, but their conspicuous spurs were mostly neglected. The appendicular or receptacular origin of these spurs has been discussed but without ontogenetic or anatomical study, and the association between spur structure and pollination systems was never assessed. We studied the spurs of species of four genera of Cerrado Vochysiaceae (tribe Vochysieae), documenting their vascularization and comparing their structure to previously described pollination systems. The spur structure was roughly similar among species, and vascularization confirmed their appendicular origin. Subepidermic secretory tissue surrounded the lumen of the spur and nectar was secreted through nectarostomata. Besides differences in size and cuticle striation, no other association between spur structure and pollination system was observed. However, the structure is somewhat distinct in Qualea parviflora, which sports a pluriseriate internal epidermis padding the spur lumen, which may provide protection against damage by the large bees that visit these relatively small flowers. The conservative histology and vasculature somewhat confirmed the monophyly of the tribe Vochysieae and the appendicular origin of the spur in the Cerrado Vochysiaceae.
\end{abstract}

Keywords: Callisthene, nectar, nectarostomata, plant anatomy, Qualea, Salvertia, Vochysia

\section{Introduction}

Nectar production and consumption have a central role in plant-animal interactions (Pacini \& Nicholson 2007) and seem to have been fundamental for the evolution of pollination mutualisms (Heil 2011; Abrahamczyk et al. 2017). Flower structure and pollination mechanisms have evolved around nectar secretory structures and characterize many different groups of Angiosperms (e.g. Endress 1994; Vogel 1997; 1998a; b; c; Bernardello 2007). These structures are key features to understand both angiosperm radiation and diversity (Friis et al. 2006; Crepet \& Niklas 2009).
In this context, the Vochysiaceae is a small family of tropical trees, which is characterized by relatively specialized spurred flowers (Kawasaki 2007). This family includes eight genera and ca. 200 species mostly in the Neotropics, but with a few species in Africa. Traditionally, the tribe Erismae includes three genera: Erisma (from the Neotropics), Erismadelphus, and Korupodendron (from Africa), all bearing epigenous flowers (Keay \& Stafleu 1952; Stafleu 1954; Kawasaki 1998; Litt \& Cheek 2002). The exclusively Neotropical tribe Vochysieae includes the remaining genera: Callisthene, Qualea, Ruizteranea, Salvertia, and Vochysia, all with hypogenous flowers (Stafleu 1948;

\footnotetext{
${ }^{1}$ Instituto de Biologia, Universidade Federal de Uberlândia, Campus Umuarama, 38405-320, Uberlândia, MG, Brazil

${ }^{2}$ In memorian. Departamento de Botânica, Universidade de São Paulo, São Paulo, SP, Brazil

*Corresponding author: carmoliveira@ufu.br
} 
1952; Marcano-Berti 1969). In this tribe the spurred flowers are predominantly zygomorphic with a single stamen and varied number of petals. Salvertia has the putatively most primitive, pentamerous flowers, which are reduced to three or less petals in Vochysia, and to a single petal in Callisthene, Qualea and Ruizteranea (Oliveira 1998).

The molecular phylogenies of the angiosperms have included the Vochysiaceae in the order Myrtales, despite their specialized and oligostemous flowers (Conti et al. 1996; 1997). More detailed molecular studies revealed some trends on the origin and distribution of the family and shed some light on the intrafamiliar organization (Litt 1999; Shimizu 2016). It seems that the ovary position and stamen placement may have been important to genera differentiation (Litt \& Stevenson 2003a; b), but the structure of the spurred flowers was never fully discussed in this context.

The spur is one of the diagnostic features of the family and it is present in all species (Warming 1875; Stafleu 1948; 1952; 1953; Kawasaki 2007). The spur has a nectary function and seems to be important for the floral biology and pollination of all Vochysiaceae (Oliveira 1998). The species occurring in Cerrado, the Neotropical savannas in Central Brazil, are pollinated by a varied array of visitors, from small bees to hawkmoths and hummingbirds (Silberbauer-Gottsberger \& Gottsberger 1975; Oliveira \& Gibbs 1994; Oliveira 1996; Oliveira 1998). Most species studied so far (all in the tribe Vochysieae) are self-incompatible and dependent on the attraction of animal pollinators to produce fruits and seeds (Oliveira 1998). However, although the spur and its nectar production are the main attractants to all floral visitors to Vochysiaceae flowers, the origin, structure, and functioning of the spur is yet to be described.

The structure and onthogenesis of nectaries may be important to understand their functional role to pollination systems (Vogel 1983; Abrahamczyk et al. 2017). Moreover, specifically for the Vochysiaceae, there has been a discussion on the appendicular or receptacular origin of these structures (Kopka \& Weberling 1984), which may be important to understand aspects of floral evolution and phylogenetic reconstruction of the family (Litt 1999; Litt \& Stevenson 2003a; b). In this sense, we studied here the possible origin, structure and some aspects of the functioning of the spur nectaries in some species of Cerrado Vochysiaceae.

\section{Materials and methods}

The study involved six species of Vochysiaceae occurring in the region of Uberlândia-MG and was carried out during the last two decades. Plant material was collected according to the flowering period of the species at the Reserva Particular do Clube Caça e Pesca Itororó (CCPIU), in the Estação Ecológica do Panga (Panga Ecological Station PES) and in the Parque do Sabiá (Sabiá City Park - SCP) natural areas, all in Uberlândia -MG. The CCPIU is 127 ha area with a long Palm swamp area with cerrado areas on both margins (Appolinário \& Schiavini 2002). The PES is a 403.85 ha preservation area $\left(19^{\circ} 09^{\prime} 20^{\prime \prime}-19^{\circ} 11^{\prime} 10^{\prime \prime} S\right.$ and $48^{\circ} 23^{\prime} 20^{\prime \prime}-48^{\circ} 24^{\prime} 35^{\prime \prime} \mathrm{W}$, and a mean altitude of $800 \mathrm{~m}$ ), $30 \mathrm{~km}$ south of the city, with most of the plant formations typical of Cerrado (Cardoso et al. 2009). The SCP is a 185 ha area inside Uberlândia, with mostly natural remnants of forest formations (Guilherme \& Nakajima 2007). The climate of the region is in the limit between $A w$ and $C_{w}$ of Köpen scale, with a rainy and warm summer and a dry and cooler winter (Rosa et al. 1991).

Vouchers of the plant material were collected and deposited at the Herbarium Uberlandensis (HUFU Universidade Federal de Uberlândia) as following: Callisthene major Mart. P.E. Oliveira 3073 (HUFU), Qualea grandiflora Mart. R. C. Oliveira 03,06 and 07 (HUFU), Q. multiflora Mart. R. C. Oliveira 05 and 10 (HUFU), Q. parviflora Mart. R. C. Oliveira 04 and 09 (HUFU), Salvertia convallariodora St. Hil. R.C. Oliveira 01 (HUFU), Vochysia cinnamomea Pohl P.E. Oliveira 3095 and R.C. Oliveira 02 and 03 (HUFU). Duplicates were also deposited at the Universidade de São Paulo Herbarium (SPF).

Floral buds in different stages (from ca. 30 days to the day before anthesis) and anthesis flowers were collected and measured. Such material was kept in distilled water and put in a 20psi vacuum chamber for 10 minutes previous to fixation. Fixation was carried out mainly in modified FAA (formalin, acetic acid, ethanol [50 \%], 1:1:18, by volume; Lersten \& Curtis 1988). After at least 48 hours, the material was transferred and kept either in Ethanol or Butanol $70 \%$ until histological preparations. We used mainly pre-anthesis buds and open flowers to examine spur structure, but early buds were sectioned and indicated in the results whenever used. Buds and flowers were dehydrated, embedded in Paraplast (Sass 1951), sectioned at 4 to $10 \mu \mathrm{m}$ thick in a Reichert-Jung 2030 rotating microtome, and stained with basic-fuchsin/astra-blue (Luque et al. 1996). Besides the permanent slide collection, we tested pre-anthesis buds and open flowers for presence of lipids using hand sections of fresh material stained with Sudan Black B and Sudan III (Grahan 1984). These sections were mounted in Kaiser glycerin jelly (Johansen 1940). Observations were done under light microscope (Zeiss Axioplan) using, in some cases, differential interference contrast (DIC). Description and terminology was based largely on Schmid (1988) and Nepi (2007).

Pre-anthesis buds and open flowers, and sometimes buds in earlier stages were cleared in a solution of basic fuchsin $1 \%$ in Potassium hydroxide $10 \%$ for vasculature analysis. Fixed samples were previously rehydrated, but we used also freshly collected buds for these analyses. Material in clearing solution was kept in an oven at $60^{\circ} \mathrm{C}$ until they were translucent. Then, samples were washed five times in distilled water and three or four times in $50 \%$ ethanol (30 minutes between baths). Afterwards, they were treated 
with $70 \%$ ethanol (acidified with hydrochloric acid) until the venation appeared in purple. Then, they were washed in plain $70 \%$ ethanol for ca. 30 minutes (adjusted from Kraus \& Arduin 1997). Cleared material was observed by using a stereomicroscope (Wild Model M3Z). Scales were obtained from a ruler photographed under the same optical conditions.

Some of the fixed material was prepared for SEM analyses. Material was further dehydrated up to $100 \%$ ethanol and critical point dried using liquid $\mathrm{CO}_{2}$ drier (Balzers CPD 030). The dried material was mounted in aluminum stubs and gold sputtered using a Sputter Coater (Balzers CPD 050). Observation were carried out in a Digital Scanning Microscope (Zeiss DSM 940) and photographed using a coupled Sinar 67 digital camera.

\section{Results}

The spur was a characteristic and evident trait in all studied species, although it varied from ca. $2 \mathrm{~mm}$ long in Callisthene major to ca. $3 \mathrm{~cm}$ long in Qualea grandiflora (Tab. 1). The spurs also varied somewhat in structure, but had in common the origin as a modification of the calix lobe. The vascular bundles supplying the spur originated at the same position in the receptacle as the bundles that supplied the other calix lobes, indicating an appendicular origin of the spur. The analyses also confirmed the nature and structure of secretory tissue of the spurs in all species. Secretory tissue occurred below the epidermis along the extension of the spur lumen. A detailed description of each nectary was based mostly on pre-anthesis and anthesis stages, when the secretory tissue seemed fully developed. The specific features of the spur are described below for Vochysia cinnamomea, Salvertia convallariodora, Callisthene major, Qualea grandiflora, Q. multiflora and Q. parviflora, and compared in Table 1.

\section{Vochysia cinnamomea}

In Vochysia cinnamomea flowers, the spur was associated with the largest calix lobe and was almost as long as the pedicel. At the beginning of anthesis, the spur turned backwards (Fig. 1A). The epidermis that recovered lumen of the spur was uniseriate, composed by cells with thin walls, and bore a striate and relatively thick cuticle (Fig. 1B-D). The epidermal cells presented thickened inner and outer periclinal walls. In the bottommost part of the lumen, the epidermis was provided with stomata (nectarostomata) associated to nectar flow (Fig. 1C). SEM analyses showed that cuticle striation did not occur on the stomata guardcells (Fig. 1D). Although we did not follow the ontogenesis of the nectarostomata, they seem to differentiate early, at least 30 days before anthesis. The sub-stomatic chamber appears to be linked to the intercellular spaces among the secretory cells.

Table 1. Morphological and anatomical features of the Vochysiaceae spur. SP - secretory parenchyma, NSP - non-secretory parenchyma, P - phloem, X - xylem.

\begin{tabular}{|c|c|c|c|c|c|c|}
\hline \multirow{3}{*}{$\begin{array}{c}\text { Spur Features } \\
\text { Size }\end{array}$} & \multicolumn{6}{|c|}{ Species } \\
\hline & V. cinammomea & S. convallariodora & C. major & Q. parviflora & Q. grandiflora & Q. multiflora \\
\hline & & & & & & \\
\hline Length (mm) & 12.6 & 20 & 2 & 8 & 30 & 8.9 \\
\hline Width $(\mathrm{mm})$ & 2.6 & 3.5 & 1 & 1.8 & 2.9 & 3.5 \\
\hline $\begin{array}{l}\text { Lumen Width (min-max } \\
\qquad-\mu \mathrm{m})\end{array}$ & $160-230$ & $220-460$ & $320-400$ & $70-210$ & ca. 700 & ca. 320 \\
\hline Epidermis* & & & & & & \\
\hline Layers & 1 & 1 & 1 & 2 a 4 & 1 & 1 \\
\hline Cuticle surface & striate & smooth & striate & striate & smooth & striate \\
\hline $\begin{array}{l}\text { Thickness (total/cuticle } \\
\qquad-\mu \mathrm{m})\end{array}$ & $38 / 6.5$ & $25 / 3.5$ & $10 / 1$ & $100 / 15$ & $40 /<1$ & $35 /<1$ \\
\hline Nectarostoma & & & & & & \\
\hline Width $(\mu \mathrm{m})$ & $15-25$ & $24-28$ & 18 & 20 a 25 & $22-30$ & $35-40$ \\
\hline Position on epidermis & level & level & level & level & level & raised \\
\hline Secretory parenchyma & & & & & & \\
\hline Layers & 4 a 5 & 7 a 8 & 5 a 7 & 4 a 7 & 4 a 5 & 7 a 10 \\
\hline Cell organization & loose & loose & dense & loose & dense & loose \\
\hline Non-secretory parenchyma & & & & & & \\
\hline Layers & 10 & 10 & 5 a 7 & 10 & 10 & 10 a 12 \\
\hline Cell organization & large cells & irregular large cells & dense small cells & irregular large cells & large cells & irregular large cells \\
\hline Vascular bundles & & & & & & \\
\hline Calix** & yes & yes & yes & yes & yes & yes \\
\hline Position & NSP & NSP & SP/NSP & NSP & NSP & NSP \\
\hline Composition & $\mathrm{P} / \mathrm{X}$ & $\mathrm{P} / \mathrm{X}$ & $\mathrm{P} / \mathrm{X}$ & $\mathrm{P} / \mathrm{X}$ & $\mathrm{P} / \mathrm{X}$ & $\mathrm{P} / \mathrm{X}$ \\
\hline
\end{tabular}

* Epidermis features from sections and SEM analyses.

** Continuity with the calix lobe. 


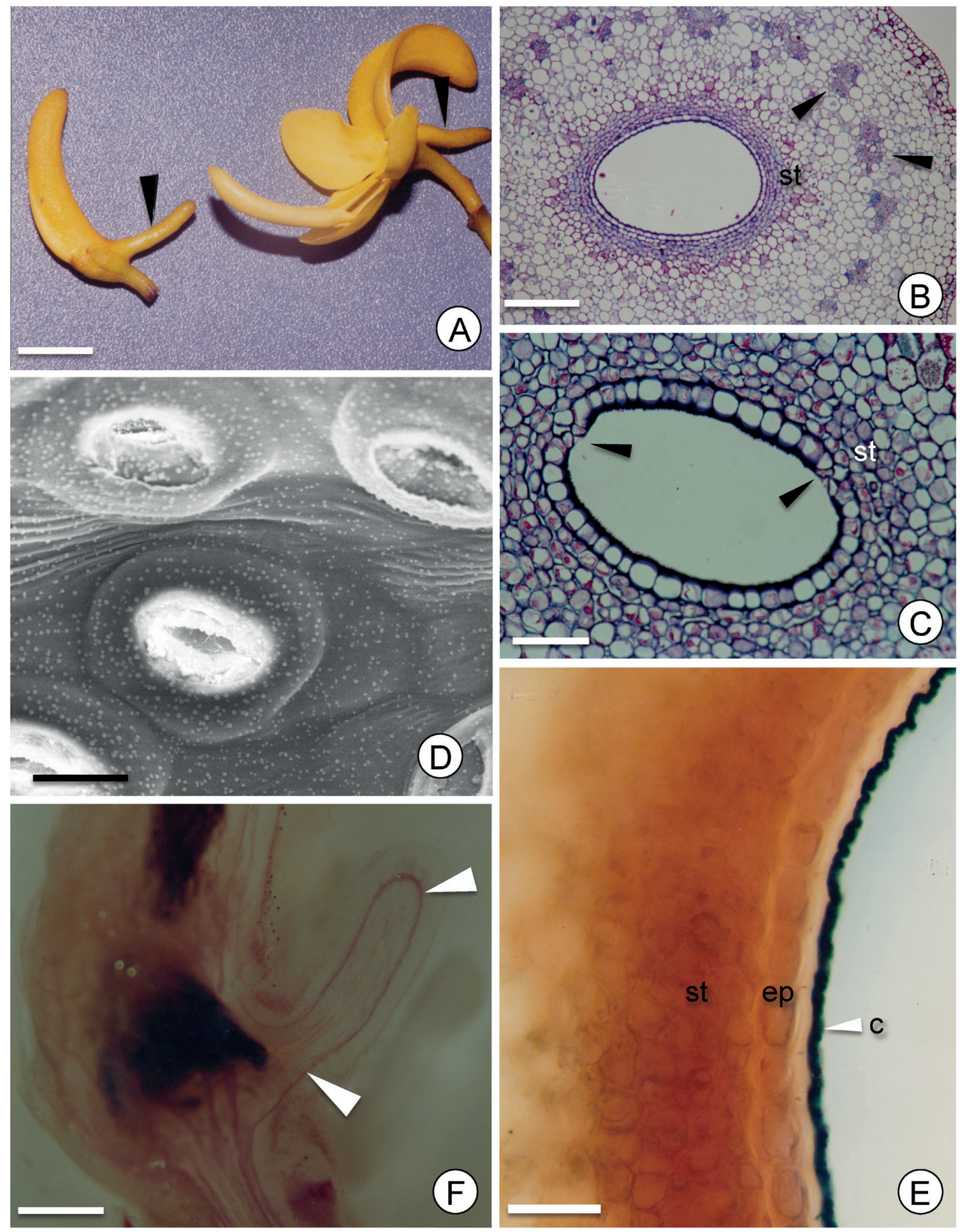

Figure 1. Vochysia cinnamomea floral nectary. A. Flower bud and a freshly open flower showing the spur (arrows). Scale bar $=1 \mathrm{~cm}$. B. Transversal section of the spur of a pre-anthesis bud showing the secretory tissue (st) around the lumen. Vascular bundles (arrows) appear amid the parenchyma of the spur mesophyll. Scale bar $=100 \mu \mathrm{m}$. C. Detail of a spur as in B with nectarostomata (arrows) on the epidermis. Scale bar $=50 \mu \mathrm{m}$. D. SEM image of a nectarostomata on the spur lumen epidermis of an anthesis flower. Scale bar $=10$ $\mu \mathrm{m}$. E. Detail of a transversal section of the spur stained with Sudan Black B showing the cuticle waxy strata on the internal surface of the spur (c), the epidermis and the secretory tissue layers. Scale bar $=50 \mu \mathrm{m}$. F. Cleared floral bud showing the main vascular bundle (arrows), which surrounds the length of the spur and continues to the spurred calix lobe. Scale bar $=1 \mathrm{~mm}$. 
The subepidermic secretory tissue presented round small cells and intercellular spaces that varied in size. The prominent nucleus and dense cytoplasm of these cells were typical of secretory tissues, and they were already vacuolated in pre-anthesis stage. The secretory tissue was formed by four or five layers of cells, but these layers were more numerous at the tip of the spur (Fig. 1B, C, E). Parenchymatic non-secretory tissue filled the space between the secretory tissue and the external epidermis of the spur (Fig. 1B). A main vascular bundle was observed around the spur (Fig. $1 F)$ and it continued to the calix lobe. Vascular bundles included phloem and xylem elements and were separated from the secretory tissue by some layers of non-secretory parenchymatic cells (Fig. 1B). We never observed any vascular branch reaching the secretory parenchyma layers.

\section{Salvertia convallariodora}

The spur of $S$. convallariodora is also very conspicuous, with almost two thirds of the bud size at pre-anthesis. In the open flower, the spur was bent backwards and parallel to the pedicel (Fig. 2A). The internal epidermis of the spur (limiting the lumen) was covered by a thick cuticle (Fig. 2B, C). Under SEM, the cuticle was smooth, with no striation (Fig. 2D). The stomata associated with nectar secretion were concentrated on the bottommost part of the spur lumen and their sub-stomatic chambers were more conspicuous than in V. cinnamomea (Fig. 2B, C).

The secretory tissue was somewhat irregular and formed by up to eight layers of round small cells, which were vacuolated at pre-anthesis (Fig. $2 \mathrm{C}$ ). Intercellular spaces were clearly connected among them and with the sub-stomatic chambers. Lipid droplets were observed in the epidermic and sub-epidermic secretory cells at pre-anthesis (Fig. 2E), but not in open flowers (Fig. 2F).

As in V. cinnamomea, vascular bundles (shown in Fig. 2B) got around the spur length through the parenchymatic tissue and continued up to the sepal. But in this species, the clearing preparation did not produce good results and are not presented. We never observed branches of vascular bundles clearing reaching the secretory parenchyma layers.

\section{Callisthene major}

The spur in flowers of $C$. major was very delicate and relatively short, less than a fourth of the pre-anthesis bud (Fig. 3A). The lumen of the spur was padded by a unilayered epidermis with a striate cuticle (Fig. 3B-D). The nectarostomata (Fig. 3B-D) were similar to the ones observed in the other species and also concentrated at the distal portion of the spur. The secretory tissue was formed by some five layers of cells with dense cytoplasm and prominent nucleus (Fig. 3B, C). The vascular bundle gets around the extension of the spur (Fig. 3E) and continues to the apex of the sepal. In this species the vascular bundles contacted directly the outer region of the secretory parenchyma.

\section{Qualea parviflora}

The spur in Q. parviflora flowers was proportionally larger than the ones in the species previously described (Fig. 4A), larger than the length of the pre-anthesis bud. The external epidermis presented tector trichomes and the lumen was padded by an uniseriate epidermis at the proximal region but bi- or pluriseriate at the median and distal portion, always with relatively thick cell walls (Fig. $4 \mathrm{~B}, \mathrm{C})$. The pluriseriate regions were the result of periclinal divisions of epidermal cells in buds some 17 days before anthesis. The epidermal cells present striate cuticle and well defined cuticular strata (Fig. 4D, E).

As in the other species, nectar flow occurs through the nectarostomata concentrated at the distal portion of the lumen of the spur (Fig. 4C). Some two days before anthesis the stomata were already open. The substomatic chamber was connected to the intercellular spaces of the secretory tissue. The secretory tissue is formed by five or six layers of cells, but up to nine layers at the distal-most portion of the spur (Fig. 4B, C, E). Secretory cells were much smaller than the epidermal cells, isodiametric, with a prominent nucleus, and loosely organized, leaving ample intercellular spaces. Some 10 days before anthesis, some cells of the secretory tissue and epidermis appeared filled with a content that stained markedly in red after treated with basic fuchsin/ astra blue double staining (Fig. 4C). As in V. cinnamomea and S. convallariodora, secretory cells already appeared vacuolated at pre-anthesis.

The main vascular bundle also followed all the extension around the spur, through the spur parenchyma, and continues to the apex of the sepal (Fig. 4B). The were also observed only within the non-secretory parenchyma. The clearing preparations, however, were not good enough, probably due to tissues thickness.

\section{Qualea grandiflora}

The spur in this species was membranaceous and developed completely only in pre-anthesis buds. At anthesis, the spur was commonly bent backwards and irregularly curved (Fig. 5A). The epidemis of the lumen of the spur appeared uniseriate (Fig. 5B-C). SEM preparations showed that the cuticle was basically smooth, except by some wavering in certain places (Fig. 5D). As in the other species, the nectar flows through the nectarostomata concentrated in the distal portion of the spur lumen (Fig. 5B-D). The substomatic chambers were relatively small and linked to minute intercellular spaces of the secretory tissue.

The secretory tissue was formed by four or five layers of small cells disposed somewhat radially in relation to the epidermis, densely arranged and with minute intercellular spaces (Fig. 5B, C). The cells presented relatively dense cytoplasm, small vacuoles and conspicuous nucleus (Fig. 5C). 

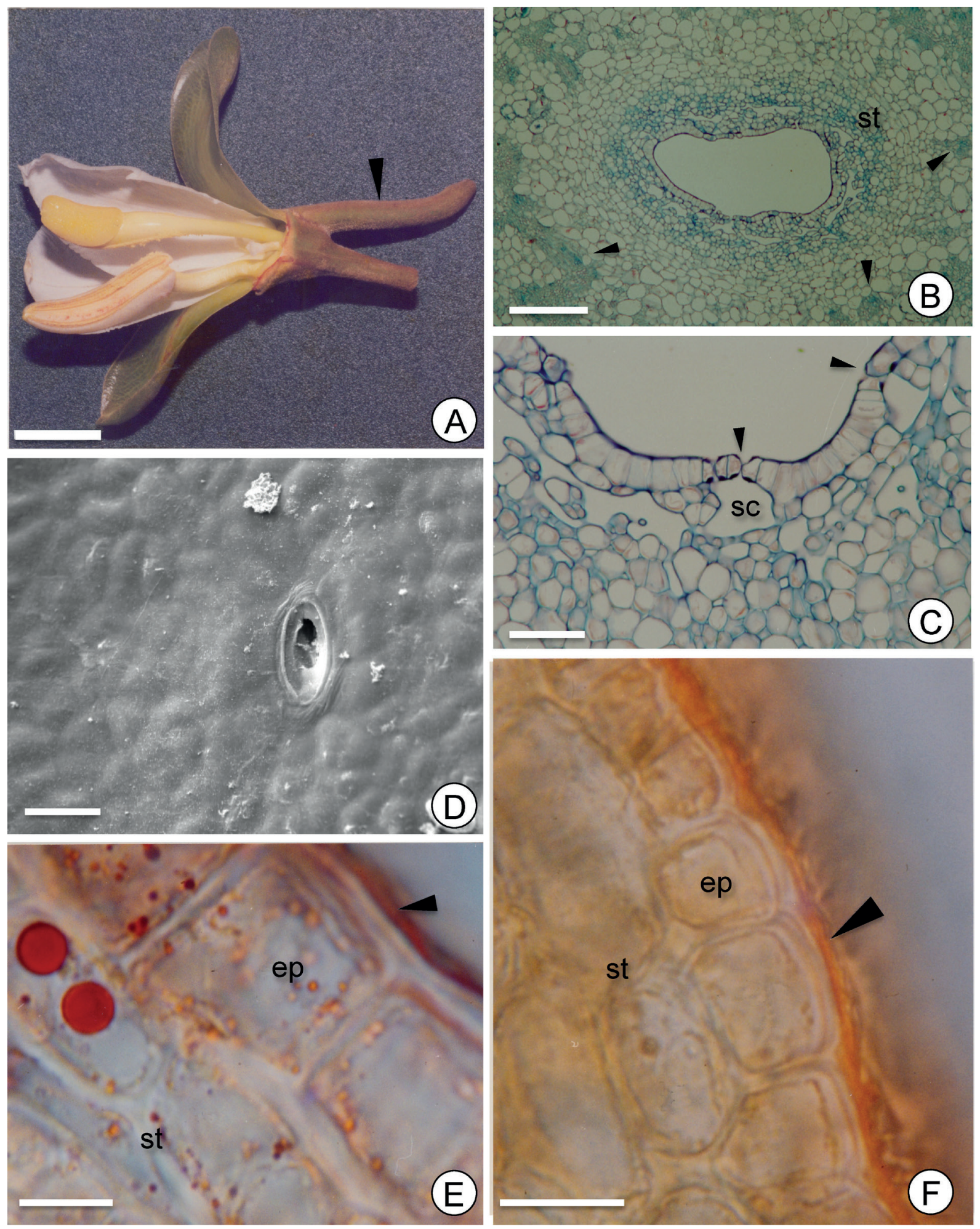

Figure 2. Salvertia convallariodora floral nectary. A. Open flower with some of the petals and calix lobes removed to show the relative size and position of the spur (arrow). Scale bar $=1 \mathrm{~cm}$. B. Transversal section of the spur showing the lumen, secretory tissue (st) and the vascular bundles (arrows) amid the parenchyma. Scale bar $=200 \mu \mathrm{m}$. C. Detail of the section in B showing the stomata on the spur lumen epidermis (arrows) and substomatic cavity (sc) connected to the secretory tissue. Scale bar $=50 \mu \mathrm{m}$. D. SEM micrography of the internal surface of the spur showing a nectarostoma and the smooth cuticle. Scale bar $=20 \mu \mathrm{m}$. E. Transversal section of the spur of a pre-anthesis bud stained with Sudan III. It is possible to observe lipid droplets (in red) in cells of the epidermis (ep) and secretory tissue (st). Note the smooth cuticle (arrow). Scale bar $=20 \mu \mathrm{m}$. F. A similar section of an open flower spur showing the cuticle (arrow), epidermis and secretory tissue with no sign of the lipid droplets observed before anthesis. Scale bar $=20 \mu \mathrm{m}$. 

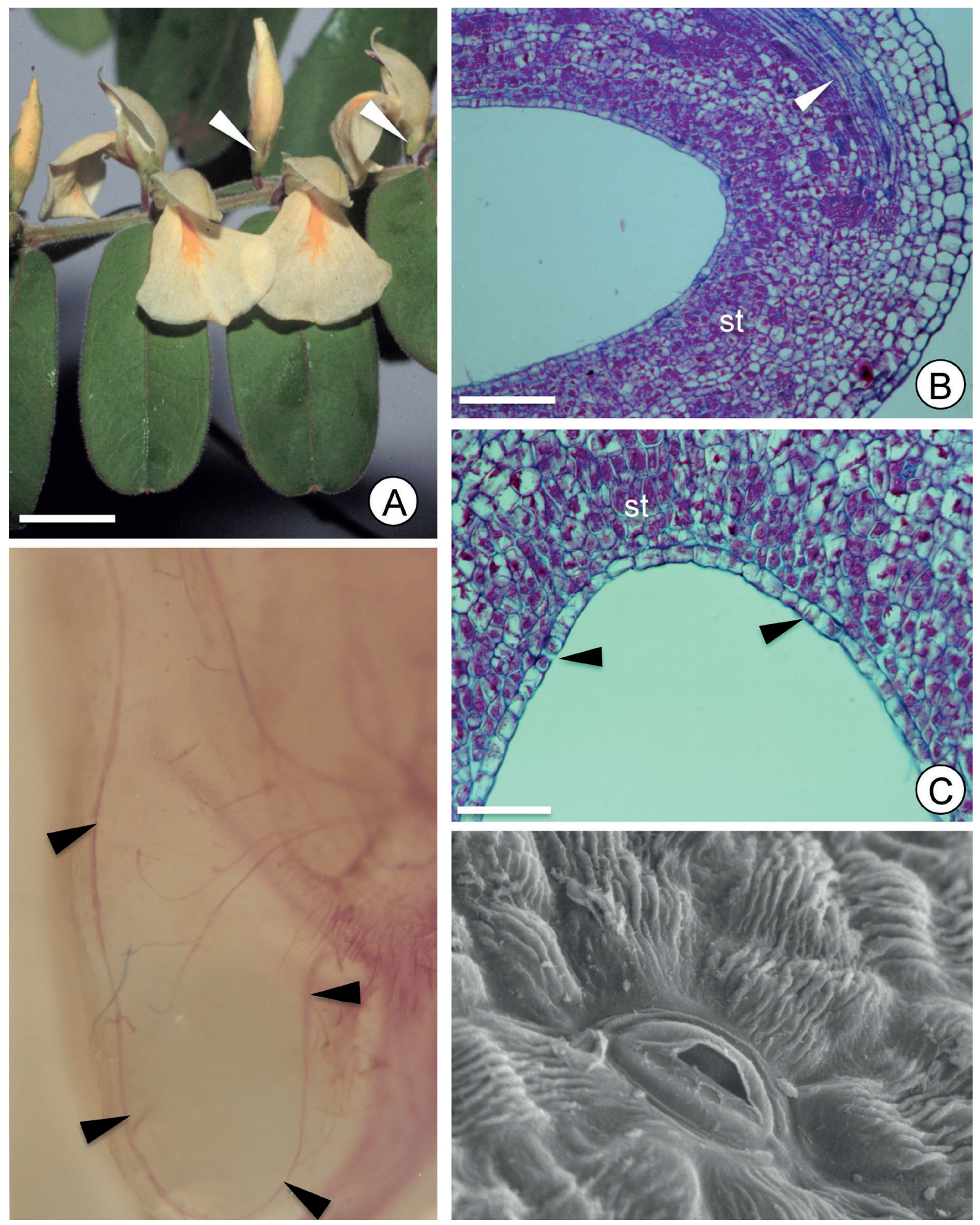

Figure 3. Callisthene major floral nectary. A. Branch with axillary buds and flowers showing the short spurs (arrows). Scale bar $=1 \mathrm{~cm}$. B. Longitudinal section of the terminal portion of the spur of a pre-anthesis bud showing the secretory tissue (st) around the lumen. Vascular bundles appear on the limit between secretory and non-secretory parenchyma (arrow). Scale bar $=100 \mu \mathrm{m}$. C. Detail of B where it is possible to see the nectarostomata (arrows) on the epidermis which covers the dense secretory tissue (st). Scale bar $=50 \mu \mathrm{m}$. D. Cleared floral bud showing the vascular bundles (arrows), which goes around the spur and continues to the calix lobe. Scale bar $=0.5 \mathrm{~mm}$. E. SEM micrography of a nectarostoma on the internal epidermis of the spur. Note the striate cuticle strata. Scale bar $=10 \mu \mathrm{m}$. 

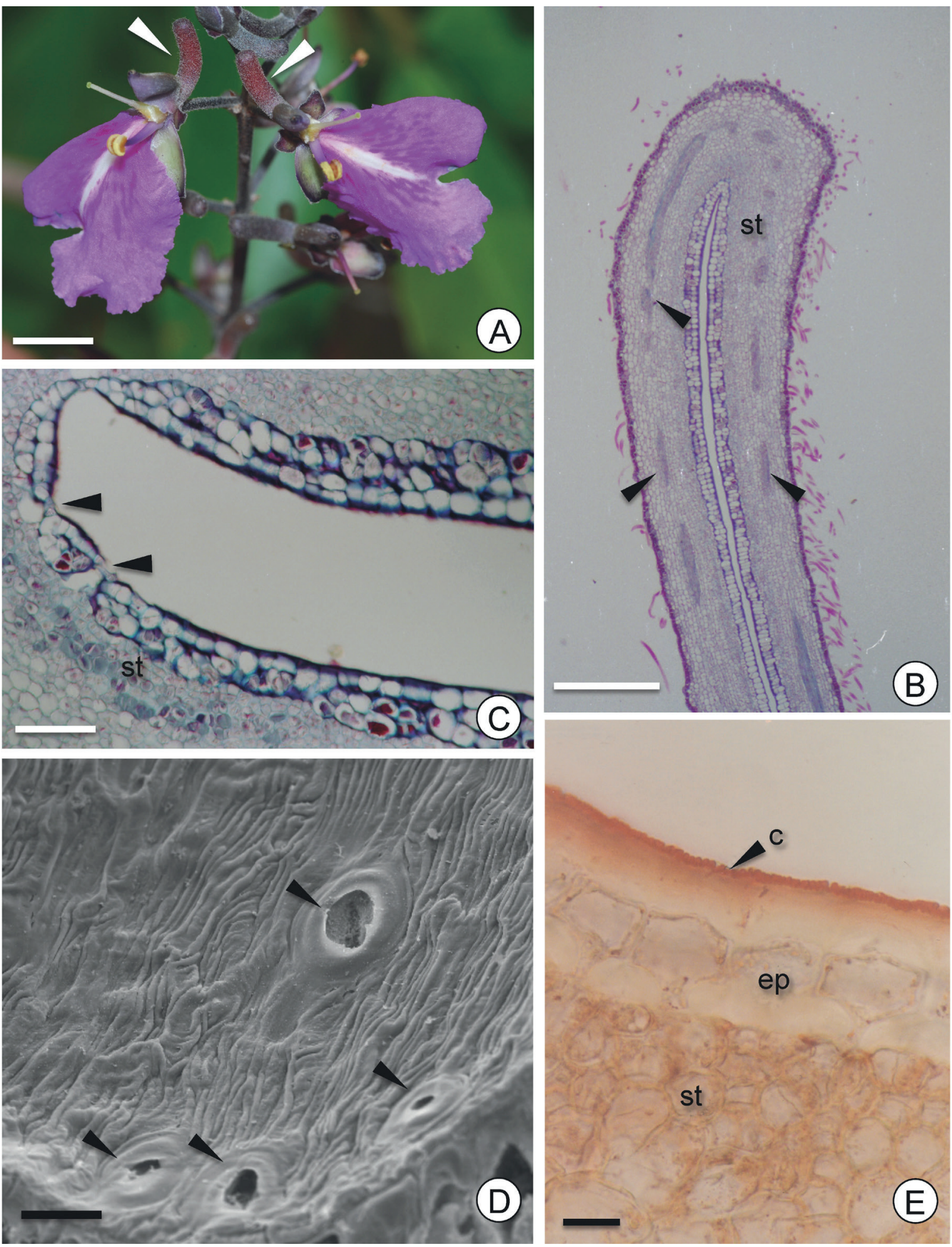

Figure 4. Qualea parviflora floral nectary. A. A pair of open flowers with prominent spurs (arrows). Scale bar $=1 \mathrm{~cm}$. B. Longitudinal section of a spur of a pre-anthesis floral bud showing the external epidermis covered by tector trichomes. The internal lumen epidermis is bi- to pluriseriate. The secretory tissue (st) appears below the epidermis all along the spur. The main vascular bundle (arrows) appear amid the parenchyma and goes around the spur length. Scale bar $=600 \mu \mathrm{m}$. C. Detail of the apex of the lumen of a similar section as in B, showing the pluriseriate epidermis (ep) with nectarostomata (arrows). Scale bar $=100 \mu \mathrm{m}$. D. SEM micrography of a section similar to $\mathrm{C}$ showing nectarostomata (arrows) concentrated in this region and the striate cuticle which recovers the epidermis of the spur lumen. Scale bar $=25$ $\mu \mathrm{m}$. E. Transversal section of the spur stained with Sudan III, showing the epidermis (ep) with a thick cuticle and cuticle strata (arrow) and the secretory tissue (st). Scale bar $=10 \mu \mathrm{m}$. 

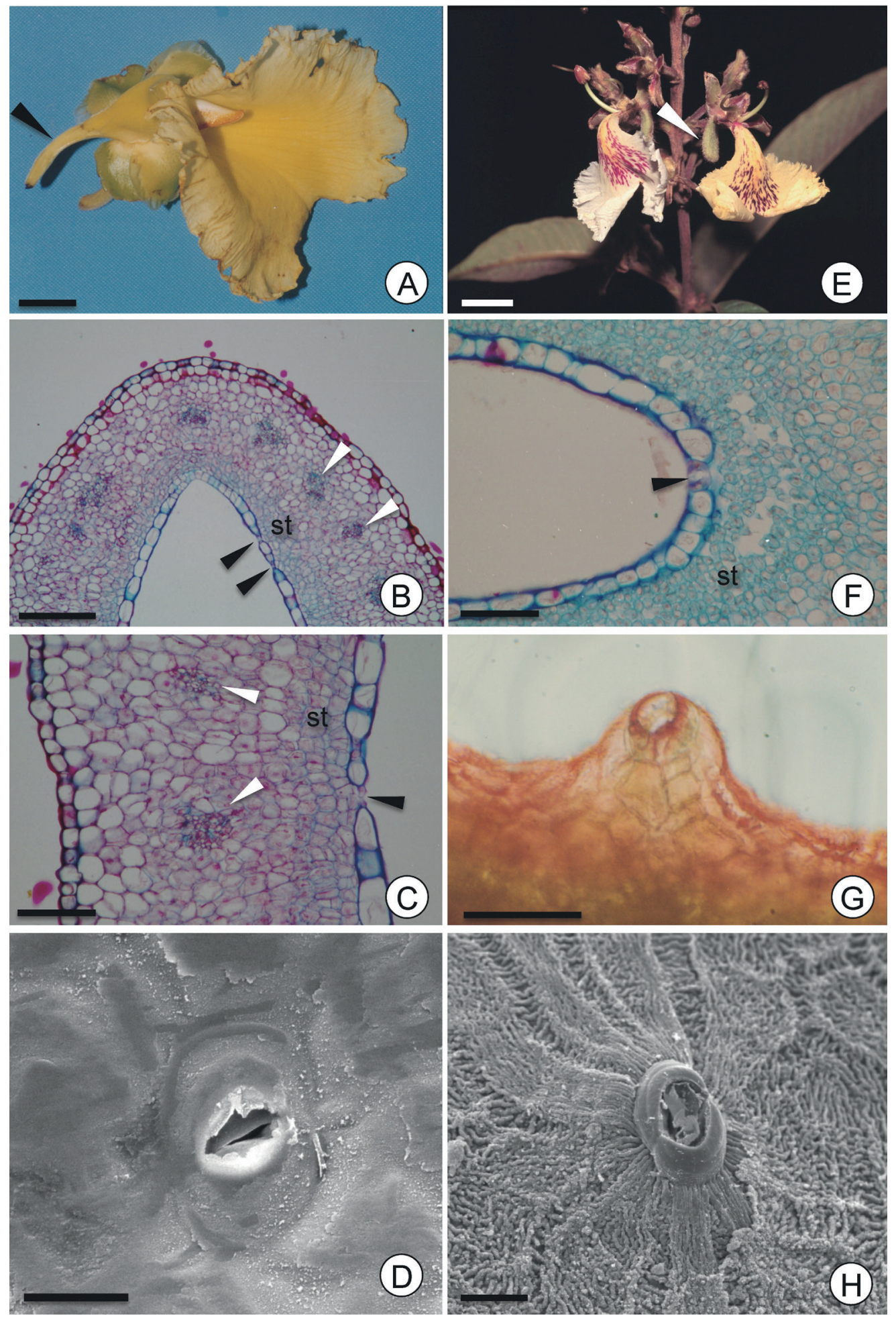

Figure 5. Qualea grandiflora and Q. muliflora floral nectaries. A. Flower of Q. grandiflora showing the membranaceous spur opposite to the large yellow petal. Scale bar $=1 \mathrm{~cm}$. B. Longitudinal section of the tip of the spur showing the nectarostomata (black arrows) on the spur lumen epidermis surface, the subepidermic secretory tissue (st) and the vascular bundles amid the non-secretory parenchyma (white arrows). Scale bar $=200 \mu \mathrm{m}$. C. Detail of the spur wall showing the nectarostoma (black arrow), the secretory tissue (st), and vascular bundles (white arrows). Scale bar $=100 \mu \mathrm{m}$. D. SEM micrography of a nectarostoma and smooth cuticle surface. Scale bar $=25$ $\mu \mathrm{m}$. E. Open flowers of Qualea multiflora with the spurs bent down (arrow). Scale bar $=1 \mathrm{~cm}$. F. Detail of the spur lumen tip showing a nectarostoma (arrow), the substomatic cavity and the small-celled secretory tissue (st) with large intercellular spaces. Scale bar $=$ $100 \mu \mathrm{m}$. G. Detail of a section of the spur showing a raised nectarostoma commonly observed in the species. Scale bar $=100 \mu \mathrm{m}$. $\mathbf{H}$. SEM micrography of the spur lumen surface with a raised nectarostoma and striate cuticle. Scale bar $=25 \mu \mathrm{m}$. 
The vascular bundles, apparently with phloem and xylem elements were observed along the length of the spur, through the parenchymatic layers (Fig. 5B, C). Clearing preparations were never satisfactory for vasculature analyses.

\section{Qualea multiflora}

In this species the spur was almost as large as the preanthesis bud and relatively more robust (Fig. 5E). The lumen epidermis was also uniseriate (Fig. 5F) and the cuticle on its cells was ornate. The nectarostomata were elevated above the cuticle (Fig. 5G). This was clearly observed both in sections and SEM analyses (Fig. 5G, H). Around the stomata, the cuticle ornament was striate and on the other cells the striate ornament entwined in a network pattern (Fig. $5 \mathrm{H}$ ). The nectar appeared to flow through the nectarostomata, which occurred in greater number at the distal portion of the lumen.

The secretory tissue was formed by up to ten layers of round cells with a prominent nucleus which were vacuolated at pre-anthesis. Large intercellular spaces were observed in the deeper layers of the secretory tissue, near the non-secretory parenchyma (Fig. 5F). These spaces were interconnected and connected with the sub-stomatic chamber. As in the other species, the vascular bundle followed the spur extension through the parenchymatic tissue and continued to the apex of the sepal. But again the clearing preparations were not good enough to presentation. Phloem and xylem elements appeared in the vascular bundles, which were restricted to the non-secretory parenchyma region.

\section{Discussion}

The spurs of the Vochysiaceae have been recognized as floral nectaries since the early treatments of the family and related with other structures with similar function in other groups of Angiosperms (Weberling 1992). Nectar is available in the spur of all species at the beginning of anthesis (Oliveira 1998), and previous studies of these nectaries describe general features, position and aspects associated with the pollination process (Elias 1983; Oliveira \& Gibbs 1994; Oliveira 1998). However, to our knowledge, only Kopka \& Weberling (1984) have focused on the origin of these structures in the Vochysiaceae, and even though they did not define the anatomy and functioning of the spurs.

The studied species presented spurs with similar structure, despite their differences in size and tissue organization. All nectaries described here can be included in the perigonal type (Fahn 1979; 1990; Bernardello 2007), since they developed in the perianth, in the calix spurred lobe. This definition of the spur as an element or structure of the calix is traditionally held in the family treatments (Warming 1875; Stafleu 1948; Kawasaki 2007). However, Kopka \& Weberling (1984) studying the spur of Vochysia acuminata, have challenged this view and suggested the Vochysiaceae spurs as homologous to the spur in Tropaeolum, which has a receptacular origin. They based their analysis on Baillon (1874) who affirmed the spur would have an axial origin. Weberling (1992) supports the axial origin of the spur in the Vochysiaceae and their similarity with the nectariferous structures of the zygomorphic flowers of the Chrysobalanaceae. However, the cited authors have not based their conclusion on vascularization evidences nor cited any study in this sense. We observed here that the spur developed after the differentiation of the calix lobes and it was supplied by the same vascular bundle. These observations corroborate the perigonal/appendicular nature of the spur in the studied species, although a detailed ontogenetic study of the origin of the spur is still lacking. A further evidence of the appendicular origin is that the spur detached together with the calix lobe during the abscission process (Oliveira 1998). The abscission zone is an appendicular feature in the Angiosperms (Addicott 1978; Endress 2008) and spur abscission confirms its association with the calix lobe.

As for the histological aspects, the nectaries can be classified in three basic types (sensu Vogel 1977; Bernardello 2007): mesenchymatous, epithelial and trichomatous. The nectaries of the studied Vochysiaceae are all of the mesenchymatous type, since they present a subepidermic secretory tissue and nectar flow through modified stomata (nectarostomata, sensu Schmid 1988 and Nepi 2007). The general structure and tissue placement is very similar among the species and genera studied here, except for Qualea parviflora where the epidermis was pluriseriate in some portions of the lumen. The epidermis of both floral and extra-floral nectaries in the angiosperms is commonly uniseriate with or without trichomes (Fahn 1979; 1990; Schmid 1988; Bernardello 2007), and there is no reference to pluriseriate epidermis or hypoderm in the studies we accessed. The pluriseriated epidermis in Qualea parviflora may be a protection against damage by visitors or desiccation. The relatively small flowers of this species are visited by relatively large bees with long proboscis, which could easily damage more delicate structures (Santos 1997). Moreover, this species flowers commonly during the dry season and are exposed to drought and high temperatures (Barbosa 1983; Santos 1997). Although pollinated by the same spectrum of bees, Q. multiflora presents a larger flower and blooms later, during the rainy season (Barbosa 1983; Oliveira 1998), which may explain its uniseriate epidermis. The spur in Q. grandiflora, membranaceous and relatively longer, did not present fundamental histological differences which could be readily associated to the hawkmoth pollination characteristic of this species (Silberbauer-Gottsberger \& Gottsberger 1975; Oliveira 1998; Oliveira et al. 2004), but it is interesting that both sphingophillous species, $Q$. grandiflora and S. convallariodora, presented smooth cuticle. As a whole, the differences in pollination systems described for the genera of Vochysiaceae in Cerrado (Oliveira 1998) 
were not reflected in marked structural or histological differences in the nectaries, except for their relative size and cuticle striation. Nectary organization and secretion mode was basically similar among the studied species.

The presence of stomata, cuticle and cuticle strata, thickened periclinal walls of the epidermis, cellular content and even size are features used to characterize epidermis tissue in perigonal nectaries (Nepi 2007). For the Vochysiaceae, we did not observe marked differences between species, except for the elevated stomata and cuticle striation of Qualea multiflora. Stomata size and distribution were not measured, but it was possible to see that they were concentrated at the distal portion of the spur lumen, where the nectariferous tissue seemed more developed and possibly where most of the nectar was actually secreted. Stomata associated to floral nectaries occur in more than 75 families of Angiosperms (Davis \& Gunning 1993; Nepi 2007) and seem to be a common feature of these secretory structures, though other forms of nectar release have been described (Bernardello 2007; Heil 2011). As observed in the Vochysiaceae, the nectarostomata associated with the spurs are structurally similar to the ones associated with gas exchange in leaves, but they commonly loose the ability to regulate the aperture, functioning only as a passive channel for the release of the nectar produced by the nectariferous substomatic tissue (Bernardello 2007; Heil 2011). In Vicia faba floral nectary, for example, the stomata have similar function as in the Vochysiaceae and their distribution also coincides with the distal-most portion of the nectary (Davis \& Gunning 1993).

The secretory tissue itself, subjacent to the epidermis, was similar to other nectariferous tissue described for the various angiosperm species already studied (Schmid 1988; Nepi 2007; Heil 2011). Parenchymatic cells with dense cytoplasm and prominent nuclei, as well as intercellular spaces for nectar flow are features commonly described for these nectaries. Vacuoles observed during anthesis are also common in the secretory tissue (Bernardello 2007) and seem to have a role in the secretory process itself (Paiva 2016).

The studied species were also similar for the vascular bundles supplying the nectaries. The presence of xylem and phloem in the bundles supplying the nectaries, as in the studied Vochysiaceae spurs, occurs in some Ranunculaceae spurred flowers (Antoń \& Kamińska 2015) and in the staminal nectaries inside Viola odorata spurs (Wiśniewska et al. 2015). But in many cases the vascular bundles are dominated by phloem or phloem elements only do irrigate the secretory parenchyma (Heil 2011; Wiśniewska et al. 2015) The vascular tissue in the nectary of Rosmarinus, for example, consists of phloem only (Zer \& Fahn 1992), and in some Ranunculaceae they are dominated by phloem (Antoń $\&$ Kamińska 2015). But not all secretory parenchyma are directly irrigated by vascular bundles or branches. As in most the Vochysiaceae studied here, vascular bundles were observed only in the non-secretory parenchyma of some of the spurred Ranunculaceae (Antoń \& Kamińska 2015), and vascularization seems to be absent in almost one third of the studied nectaries (Fahn 1979; Heil 2011).

The proportion of vascular tissue supplying the nectary seems to be related with nectar sugar concentration, and those supplied by both xylem and phloem or xylem only usually secrete low sugar content nectar (Zer \& Fahn 1992; Bernardello 2007). We did not estimate the proportion of xylem and phloem in the vascular bundles supplying the Vochysiaceae spurs. However, preliminary observations indicate the predominance of phloem elements in the vascular bundle supplying Callisthene major spur. Moreover, the vascular bundles are in direct contact with the secretory parenchyma. In this species, sugar content may be as high as $66 \%$ (AP Afonso unpubl. res., Oliveira 1998), somewhat confirming the relationship.

The results presented here show a conservative spur structure in species of the different genera of the tribe Vochysieae in spite of their varied pollination systems. This somewhat confirms the monophyly of the tribe and corroborates the appendicular origin of the nectary in the family Vochysiaceae.

\section{Acknowledgements}

We thank the CNPq, FAPEMIG and CAPES for funding different stages of this study. The original set of data was part of the Doctoral thesis of the first author but the data and complementary information were thoroughly revised and updated during a CAPES - Estágio Senior sabbatical period in the University of Tennessee, at Dr. Joseph Williams Lab.

\section{References}

Abrahamczyk S, Kessler M, Hanley D, et al. 2017. Pollinator adaptation and the evolution of floral nectar sugar composition. Journal of Evolutionary Biology 30: 112-127.

Addicott FT. 1978. Abscission strategies in the behavior of tropical trees. In: Tomlinson PB, Zimmermann M. (eds.) Tropical trees as living systems. Cambridge, Cambridge University Press. p. 318-398.

Antoń S, Kamińska M. 2015. Comparative floral spur anatomy and nectar secretion in four representatives of Ranunculaceae. Protoplasma 252: 1587-1601.

Appolinário V, Schiavini I. 2002. Levantamento fitossociológico de espécies arbóreas de cerrado (stricto sensu) em Uberlândia - Minas Gerais. Boletim do Herbário Ezechias Paulo Heringer 10: 57-75.

Baillon H. 1874. Histoire des Plantes V. Paris, L Hachette.

Barbosa AA. 1983. Aspectos da biologia reprodutiva de três espécies de Qualea (Vochysiaceae) de um cerrado de Brasília-DF. MSc Thesis, Universidade de Brasília, Brasília.

Bernardello G. 2007. A systematic survey of floral nectaries. In: Nicholson SW, Nepi M, Pacini E. (eds.) Nectaries and nectar. Dordrecht, Springer. p. $19-128$.

Cardoso E, Moreno MIC, Bruna EM, Vasconcelos HL. 2009. Mudanças fitofisionômicas no cerrado: 18 anos de sucessão ecológica na estação ecológica do Panga, Uberlândia - MG. Caminhos de Geografía 10: 254-268.

Conti E, Litt A, Sytsma KJ. 1996. Circumscription of Myrtales and their relationships to other Rosids: evidence from $\mathrm{RBcL}$ sequence data. American Journal of Botany 83: 221-233. 
Conti E, Litt A, Wilson PG, Graham SA, Briggs BG, Johnson LAS, Sytsma KJ. 1997. Interfamilial relationships in Myrtales: molecular phylogeny and patterns of morphological evolution. Systematic Botany 22: 629-647.

Crepet WL, Niklas KJ. 2009. Darwin's second "abominable mystery": Why are there so many angiosperm species? American Journal of Botany 96:366-381.

Davis AR, Gunning BES. 1993. The modified stomata of the floral nectary of Vicia faba L. 3. Physiological aspects, including comparisons with foliar stomata. Plant Biology 3: 241-253.

Elias TS. 1983. Extrafloral nectaries: Their structure and distribuition. In: Bentley BL, Elias TS. (eds.) The biology of nectaries. New York, Columbia University Press. p. 174-203.

Endress PK. 1994. Floral structure and evolution of primitive angiosperms: recent advances. Plant Systematics and Evolution 192: 79-97.

Endress PK. 2008. Perianth biology in the basal grade of extant angiosperms. International Journal of Plant Sciences 169: 844-862.

Fahn A. 1979. Secretory tissues in plants. London, Academic Press.

Fahn A. 1990. Plant anatomy. 4th. edn. Oxford, Pergamon Press.

Friis EM, Pedersen KR, Crane PR. 2006. Cretaceous angiosperm flowers: innovation and evolution in plant reproduction. Palaeogeography, Palaeoclimatology, Palaeoecology 232: 251-293.

Grahan PB. 1984. Plant histochemistry and cytochemistry: An introduction. London, Academic Press.

Guilherme FAG, Nakajima JN. 2007. Estrutura da vegetação arbórea de um remanescente ecotonal urbano floresta-savana no Parque do Sabiá, em Uberlândia, MG. Revista Árvore 31: 239-337.

Heil M. 2011. Nectar: generation, regulation and ecological functions. Trends in plant science 16: 191-200.

Johansen DA. 1940. Plant microtechnique. New York, McGraw Hill.

Kawasaki ML. 1998. Systematics of Erisma (Vochysiaceae). Memoirs of the New York Botanical Garden 81.

Kawasaki ML. 2007. Vochysiaceae. In: Kubitzki K. (ed.) Flowering plants: Eudicots. Heidelberg, Springer. p. 480-487.

Keay RWJ, Stafleu FA. 1952. Erismadelphus. Acta Botanica Neerlandica 1: 594-599.

Kopka S, Weberling F. 1984. Zur morphologie und morphogenese der blute von Vochysia acuminata Bong. subsp. laurifolia (Warm.) Stafleu (Vochysiaceae). Beitrage zur Biologie der Pflanzen 59: 273-354.

Kraus J, Arduin M. 1997. Manual básico de métodos em morfologia vegetal. Seropédica, EDUR.

Lersten NR, Curtis JD. 1988. Secretory reservois (ducts) of two kinds in giant ragweed (Ambrosia trifida; Asteraceae). American Journal of Botany 75: 1313-1323.

LittA. 1999. Floral morphology and phylogeny of Vochysiaceae. PhD Thesis, City University of New York, New York.

Litt A, Cheek M. 2002. Korupodendron songweanum, a new genus and species of Vochysiaceae from West-Central Africa. Brittonia 54: 13-17.

Litt A, Stevenson DW. 2003a. Floral development and morphology of Vochysiaceae. I. The structure of the gynoecium. American Journal of Botany 90: 1533-1547.

Litt A, Stevenson DW. 2003b. Floral development and morphology of Vochysiaceae. II. The position of the single fertile stamen. American Journal of Botany 90: 1548-1559.

Luque R, Souza HC, Kraus JE. 1996. Método de coloração de Roeser (1972) - modificado - Kropp (1972) visando a substituição do azul de astra por azul de alcião 8GS ou 8GX. Acta Botanica Brasilica 10: 199-212.

Marcano-Berti L. 1969. Ruizterania. Pittieria 2: 6-27.

Nepi M. 2007. Nectary structure and ultrastructure. In: Nicholson SW, Nepi M, Pacini E. (eds.) Nectaries and nectar. Dordrecht, Springer. p. 129-166.

Oliveira PE. 1996. Biologia floral de Salvertia convallariodora (Vochysiaceae): uma espécie de cerrado polinizada por mariposas. Revista Brasileira de Botânica 19: 49-53.
Oliveira PE. 1998. Reproductive biology, evolution and taxonomy of the Vochysiaceae in Central Brazil. In: Owens S, Rudall P. (eds.) Reproductive Biology 96. Richmond, Royal Botanic Gardens at Kew. p. 381-393.

Oliveira PE, Gibbs PE. 1994. Pollination and breeding systems of six Vochysia species (Vochysiaceae) in Central Brazil. Journal of Tropical Ecology 10: 509-522.

Oliveira PE, Gibbs PE. Barbosa AA. 2004. Moth pollination of woody species in the Cerrados of Central Brazil: a case of so much owed to so few? Plant Systematics and Evolution 245: 41-54.

Pacini E, Nicholson SW. 2007. Introduction. In: Nicholson SW, Nepi M, Pacini E. (eds.) Nectaries and nectar. Dordrecht, Springer. p. 1-18

Paiva EAS. 2016. How do secretory products cross the plant cell wall to be released? A new hypothesis involving cyclic mechanical actions of the protoplast. Annals of Botany 117: 533-540.

Rosa R, Lima SC, Assunção WL. 1991. Abordagem preliminar das condições climáticas de Uberlândia (MG). Sociedade e Natureza 3: 91-108.

Santos ML. 1997. Biologia de Polinização e Reprodução de Callisthene fasciculata e Qualea parviflora em cerrado sobre afloramento basáltico, Araguari-MG. MSc Thesis, Universidade de Brasília, Brasília.

Sass JE. 1951. Botanical microtechnique. 2nd. edn. Ames, The Iowa State College Press.

Schmid R. 1988. Reproductive versus extra-reproductive nectaries- historical perspective and terminological recommendations. Botanical Review 54: 179-232.

Shimizu GH. 2016. Estudos filogenéticos, taxonômicos e nomenclaturais em Vochysiaceae e sinopse de Vochysia no Brasil. PhD Thesis, Universidade Estadual de Campinas, Campinas.

Silberbauer-Gottsberger I, Gottsberger G. 1975. Uber sphingophile angiopermen brasiliens. Plant Systematics and Evolution 123: 157-184.

Stafleu FA. 1948. A monography of the Vochysiaceae. I- Salvertia and Vochysia. Recueil du Travaux Botanique Neerlandais 41: 397-540.

Stafleu FA. 1952. A monography of the Vochysiaceae II - Callisthene. Acta Botanica Neerlandica 2: 222-242.

Stafleu FA. 1953. A monography of the Vochysiaceae lll-Qualea. Acta Botanica Neerlandica 2: 144-21.

Stafleu FA. 1954. A monography of the Vochysiaceae IV- Erisma. Acta Botanica Neerlandica 3: 459-480.

Vogel S. 1977. Nektarien und ihre okologische Bedeutung. Apidologie 8: 321-335.

Vogel S. 1983. Ecophysiology of zoophilic pollination. In: Lange OL, Nobel PS, Osmond CB, Ziegler H. (eds.) Encyclopedia of plant physiology, New series Vol 12C: Physiological plant ecology III. Berlin, Springer. p. $559-624$

Vogel S. 1997. Remarkable nectaries: structure, ecology, organophyletic perspectives. I. Substitutive nectaries. Flora 192: 305-333.

Vogel S. 1998a. Remarkable nectaries: structure, ecology, organophyletic perspectives. II. Nectarioles. Flora 193: 1-29.

Vogel S. 1998b. Remarkable nectaries: structure, ecology, organophyletic perspectives. III. Nectar ducts. Flora 193: 113-131.

Vogel S. 1998c. Remarkable nectaries: structure, ecology, organophyletic perspectives. IV. Miscellaneous cases. Flora 193: 225-248.

Warming E. 1875. Vochysia. In: Martius KFP. (ed.) Flora Brasiliensis. XIII, tomo II. Munich, Oldenbourg. p. 18-116.

Weberling F. 1992. Morphology of flower and inflorescences. Cambridge, Cambridge University Press.

Wiśniewska N, Bohdanowicz J, Kowalkowska AK. 2015. Micromorphology and ultrastructure of the floral nectaries of Viola odorata L. (Violaceae). Modern Phytomorphology 7: 59-66.

Zer H, Fahn A. 1992. Floral nectaries of Rosmarinus officinalis L. Structure, ultrastructure and nectar secretion. Annals of Botany 70: 391-397. 